\title{
Closed-Loop Biodigesters on Small-Scale Farms in Low- and Middle-Income Countries: A Review
}

\author{
Isha Kulkarni ${ }^{1}\left(\mathbb{D}\right.$, Joachim Werner Zang ${ }^{2}{ }^{\mathbb{D}}$, Wilson M. Leandro ${ }^{3}$, Priti Parikh ${ }^{4} \mathbb{D}$, Ilan Adler ${ }^{1}$, \\ Warde A. Da Fonseca-Zang ${ }^{2}$ and Luiza C. Campos ${ }^{1, *(\mathbb{D})}$
}

1 Department of Civil, Environmental \& Geomatic Engineering, Faculty of Engineering Sciences, University College London-UCL, Gower Street, London WC1E 6BT, UK; isha.kulkarni.16@ucl.ac.uk (I.K.); ilan.adler.09@ucl.ac.uk (I.A.)

2 Sustainable Process Technology, Department 2, Federal Institute of Goiás, IFG-Goiânia, Rua 75, 46, Centro, CEP 74055110 Goiânia-GO, Brazil; joachim.zang@ifg.edu.br (J.W.Z.); warde.zang@ifg.edu.br (W.A.D.F.-Z.)

3 Agronomy Faculty of the Federal University of Goiás, EA-UFG, Universidade Federal de Goiás Rodovia Goiânia-Nova Veneza, Km 0 s/n Campus-Samambaia, CEP 74690900 Goiânia-GO, Brazil; wilson.leandro@ufg.br

4 Engineering for International Development Centre, Bartlett School of Sustainable Construction, Faculty of the Built Environment, University College London, 1-19 Torrington Place, London WC1E 7HB, UK; priti.parikh@ucl.ac.uk

* Correspondence: 1.campos@ucl.ac.uk

Citation: Kulkarni, I.; Zang, J.W.; Leandro, W.M.; Parikh, P.; Adler, I.; Da Fonseca-Zang, W.A.; Campos, L.C. Closed-Loop Biodigesters on Small-Scale Farms in Low- and Middle-Income Countries: A Review. Water 2021, 13, 2744. https:// doi.org/10.3390/w13192744

Academic Editor: Antonio Panico

Received: 14 August 2021

Accepted: 29 September 2021

Published: 2 October 2021

Publisher's Note: MDPI stays neutral with regard to jurisdictional claims in published maps and institutional affiliations.

Copyright: (c) 2021 by the authors. Licensee MDPI, Basel, Switzerland. This article is an open access article distributed under the terms and conditions of the Creative Commons Attribution (CC BY) license (https:// creativecommons.org/licenses/by/ $4.0 /)$.

\begin{abstract}
Anaerobic digestion (AD) systems are prominent in low- and middle-income countries (LMICs), although their implementation within organic farms to enhance resource efficiency and "close the loop" has been limited. This paper thus reviewed existing literature on the potential of AD technologies as part of closed-loop rural family farming communities in LMICs. Data from eleven existing case studies matching this criterion was then collated to understand practical considerations of implementing and maintaining viable AD systems for small farmers. The case studies analyzed indicate that most, if not all, of the biogas produced in the AD process is used for household purposes such as cooking, lighting and heating. The AD systems are either based on the fixed biogas dome or the floating drum design, although the tubular flexible balloon model is mentioned as a lowcost alternative. Future research opportunities in this topic include studying the applicability of recommendations offered across different geographies, consideration of long-term sustainability and impact of biodigester technology, and sociocultural factors such as community ownership and indigenous practices.
\end{abstract}

Keywords: organic farming; closed-loop systems; anaerobic biodigesters; small-scale rural farming; waste-water-energy-food nexus

\section{Introduction}

Organic agriculture is a method of farming that seeks to produce food with minimal impact to ecosystems, animals or humans [1]. It encompasses a number of environmentally friendly practices such as avoiding pesticide use, increasing abundance of species, increasing soil fertility, reducing soil erosion, and reducing energy usage and nitrogen (N) losses from the system [2-6].

As of 2019, organic agriculture systems covered 72.3 million hectares globally (about $1.5 \%$ of all global agricultural land). More than a fifth of all organic agricultural land is located in low- and middle-income countries that are recipients of official development assistance (ODA) [7]. This may be attributed to the often-limited access of small-scale farmers in such environments to chemical fertilizers, improved seeds, irrigation water and pesticides, caused by their lack of capital, infrastructure and market access [8]. In such a context, "closing the nutrient cycle" — recycling nutrients and organic matter-is 
a necessity, and innovation regarding this form of resource efficiency is hence a constant theme in the development of agriculture technology [9].

Closing the nutrient cycle can be directly connected with a range of rural organic farming challenges, especially in low- and middle-income countries (LMICs), leading to the requirement for holistic, closed-loop systems to improve agricultural productivity while also facilitating lasting sustainable development. With the integration of food production and upcycling of waste (agricultural, animal, food and human) into the water, sanitation and energy nexus, closed-loop systems promote Water-Waste-Energy-Food (WWEF) models. Sustainable decentralized technology recovering nutrients, water and energy from waste streams to provide clean streams, concentrated fertilizers and energy is a necessity in small-scale agriculture.

Anaerobic digestion $(\mathrm{AD})$ provides an opportunity to integrate waste management into food, energy and agricultural systems $[10,11]$. Agro-industrial waste generates three quarters of the potential of raw materials suitable for biogas production. The natural biodegradation of organic matter in anaerobic conditions releases between 590 and 800 million tons of methane into the atmosphere globally each year [12]. Such extensive potential leads us to consider different perspectives for biogas in various fronts, such as improving waste treatment processes of solids and sewage, the process of heat and energy, the purification of the product to make it compatible with the existing uses of natural gas, and in the chemical extraction. Biogas recovery systems convert various types of biomasses, taking advantage of the biogas released as an energy source. Challenges posed in the sector include the cost of technologies and, consequently, the dependence on incentives to leverage the market in LMICs for personal use, especially in small and medium-sized rural properties [13].

By definition, the $\mathrm{AD}$ process requires anaerobic conditions to guarantee the joint activity of an association of micro-organisms to transform raw organic material into methane ( $50-75 \%$ by volume) and carbon dioxide ( $25-50 \%$ by volume). Biogas may also contain small amounts of hydrogen sulfide $\left(\mathrm{H}_{2} \mathrm{~S}\right)$, ammonia $\left(\mathrm{NH}_{3}\right)$ and other trace gases. The biogas composition depends on the organic substrates and the type of $\mathrm{AD}$ technology used [14].

The process comprehends the four phases of hydrolysis, acidogenesis, acetogenesis and methanogenesis. Different groups of micro-organisms in synthrophy are required in each phase. The main environmental conditions of $\mathrm{AD}$ are the process temperature, $\mathrm{pH}$ and dry matter concentration (\%), among others. However, the main aspect of an $\mathrm{AD}$ is the biodigester model used which has to be adapted to the environmental conditions, type of substrate, and available financial resources [15].

Agricultural waste, animal dung, among other organic effluents, can be used in the biodigester. The biogas can be directly applied for household cooking, or as fuel in lamps, or for internal combustion engines. For example, in Brazil, manure from two to four cows can produce 2 to $3 \mathrm{~m}^{3}$ of biogas to supply cooking gas for a family of five to six people. The digested material can fertilize 0.5 hectare of the property $[16,17]$. Under anaerobic conditions, biogas can be produced from most organic matter. The process efficiency is influenced by the used raw material and the complexity of the AD system, e.g., if temperature could be controlled or if a mixture system is available $[16,17]$.

A decentralized biodigester is a small-scale biodigester that produces biogas which can be used as an energy source, while the sludge i.e., the digested waste, can be used as an organic, mineral-rich fertilizer [18]. This fertilizer and biogas can present a potential revenue stream for farms [19]. Figure 1 depicts a simplified flow diagram of closed-loop AD in agriculture. Apart from the environmental benefits, on-farm digesters are capable of creating energy security in agriculture while diversifying farm income and increasing employment opportunities [20]. 




Figure 1. A summary flow diagram of anaerobic digestion on a closed-loop system on farms.

The animal wastes normally used in biogas production are dung of swine, cattle, goats, poultry, among others. It is also important to consider the differences in animal production systems, which can have a relevant effect on the amount of dry matter in waste. The organic residues of agriculture and livestock are good substrates for co-digestion. Manure comprises a good load of micro-organisms, a high amount of nutrients, and favors the buffering capacity to control the $\mathrm{pH}$, ensuring the process stability.

If human blackwater is mixed with animal and agricultural wastes and dissolved in water, it will give off biogas as it decomposes in anaerobic conditions under the correct temperature [21]. Animal husbandry plays a part in the ecosystem of the farm; hence, for rural sanitation, a co-digestion of animal effluent (e.g., fresh cattle manure) and domestic sewage are emphasized [22,23].

The design of anaerobic digesters involves a range of variables that can be modified to affect biogas yield as desired. Micro-digesters in small-scale settings are perhaps more complex, considering that these can also be influenced by local contexts and traditional practices [24]. The consequent disparity in the design and operations of micro-digesters merits further examination, so that developing and sharing the best practices can be possible.

Understanding traditional practices carried out when adapting AD technology to small-scale farms involves understanding how variability in technical factors influences products. Additionally, studying the processes required to sustain this technology-the maintenance procedures and the management of biogas and digestate within a decentralized, small-scale agriculture context-is important [18]. This is especially relevant as the scope of AD goes beyond domestic systems to closed-loop, farm-scale installations. With AD technology being utilized across the globe in LMICs such as in Asia, Africa and Central America, collating strategies used to optimize closed-loop agriculture technology in a rural setting is of paramount importance [12].

Thus far, small-scale biogas technology in rural contexts in LMICs has been reviewed by Pilloni and Hamed [25]. While that research provides an overview of design characteristics, materials, and feedstock used across the world, it largely considers household settings for digesters. Given that organic agriculture has been lauded to have the potential for meaningful sustainable development in LMICs [26], there arises a need to review AD technology used across the globe to sustain a closed-loop system within farms.

Implemented anaerobic digesters in closed-loop, small-scale, rural, organic farms have not been reviewed before. With that in mind, this review examines implemented decentralized AD systems in rural small farming environments in LMICs and reports salient features utilized by them. Using these, it develops a set of potential inferences and recommendations on $\mathrm{AD}$ technology in such settings and provides a direction for future research. 


\section{Materials and Methods}

In order to draw insights and conclusions on AD technology, it is necessary to document the design and management parameters followed in different models around the world. Sufficient information may be gleaned from case studies and review articles that are likely to outline the processes followed in certain depth.

A structured review process was conducted to locate such case studies and review articles based on closed-loop rural small agriculture technology. The research questions were defined as:

1. What are the technologies being used for closed-loop systems in rural farming to recover nutrients and energy?

2. What are the system models integrating production of gas/energy, clean water and nutrients, and where are they being used?

3. How do these models operate and how are they maintained, and consequently, how economically efficient are they?

Considering these research questions, the following search terms were used to look through databases: "closed-loop", "agriculture", "rural farming", "organic farming", "nutrient recovery", "anaerobic digestion", "biogas" and "micro-digester".

General databases SpringerLink, ScienceDirect, SCOPUS, ResearchGate, Google Scholar, JSTOR, and subject-specific databases AGRIS, ASCE Library, ICE Library and osti.gov were searched to identify relevant literature. Once relevant literature was identified, inclusion criteria as outlined below was used to filter the case studies to be used for the purpose of the review:

1. Is the system fully closed-loop?

2. Does the system studied meet the set research question i.e., is it based in a rural, small farm, ideally in LMICs?

3. Does the study include details on how the system operates and is maintained?

Generally, papers were screened by first evaluating titles and keywords only. Further, abstracts were examined to ensure relevance and the final set of studies used were fully read through and studied. A specific timeframe for review was not defined.

Study quality was initially assessed by ensuring the use of peer-reviewed literature to guarantee validity and reliability of data. This included research articles and conference papers, as well as review papers. During the screening process, however, it was determined that due to the highly academic and publication-focused nature of the review, documentation that, while not peer-reviewed, might still be considered reliable, was being neglected. This included project reports and dissertations available online with same previously used search terms.

The review helped to identify the following factors as essential in implementing and maintaining a viable AD system: specifications of the model, cost, feedstock and pre-treatment, biogas management and digestate management. Data regarding these was extracted, analyzed, and discussed to provide evidence from literature, and used to formulate recommendations for a closed-loop small-scale agriculture system in LMICs.

\section{Results}

\subsection{Technical Aspects of AD Systems}

The literature review revealed that continuous mixing digesters (CFSTR-Continuous Flow Stirred Tank Reactor) are the standard technology for AD of denser substrates (total solids of up to $15 \%$ ), with favorable characteristics for pumping and mixing. The CFSTR technology is more applied in the agroindustry and in the treatment of sanitary sludge, being used less frequently in waste treatment of urban organic products, as the technology requires substrates practically free of impurities and sufficiently moist. The CFSTR is efficient for agricultural substrates with volumetric loads of 2 to $4 \mathrm{~kg}$ of volatile organic solids per $\mathrm{m}^{3}$ of effective digester volume per day $\left(2-4 \mathrm{kgVOS} / \mathrm{m}^{3}\right.$.day), and a hydraulic 
retention time of more than 20 days, producing between 0.7 and $3 \mathrm{~m}^{3}$ of biogas per $\mathrm{m}^{3}$ of digester per day, depending on the substrate and temperature used [27].

An alternative technology to CFSTR for the farming sector is covered anaerobic lagoons (PVC covers for biogas storage), which are relatively low cost and easy to build, and are used for the treatment of effluents from agriculture, livestock, industry (dairy, meat and others) and sanitary sewage treatment. These covered ponds are mostly used in tropical regions, where the atmospheric heat can maintain the temperature in the biodigester. The lagoons are not able to adequately treat the effluents if they do not have effective coverage, releasing methane gas into the atmosphere.

The efficiency of $\mathrm{AD}$ systems has a direct correlation to a range of factors, such as ambient temperature, feedstock, feedstocks mixing procedures, retention time, loading rate and system specification [28].

Recommendation for pathogenic removal in the AD is the Hydraulic Retention Time (HRT), which depends on the temperature in the digester conditions, and, considering the ambient temperature range from 20.0 to $35.0^{\circ} \mathrm{C}$, the HRT would be at least 20 days [29].

Pathogen removal commences at 1 month, or 30 days, however, only some pathogens are removed after this time. The 60 days HRT is recommended for highly pathogenic substrates; however, empirical indicators cannot substitute analytical testing in a laboratory for Escherichia coli count and helminth egg counts [30].

There are advantages of covered lagoon technology, compared to a CFSTR bioreactor, such as construction simplicity, operation and maintenance, and related reduced costs. In contrast, a larger surface area is required for construction in order to meet the low organic volumetric load supported by the system, i.e., between 0.25 and $1.00 \mathrm{~kg}$ of chemical oxygen demand (COD) $/ \mathrm{m}^{3}$.day, resulting in a hydraulic retention time (HRT) of three to six days $[31,32]$.

\subsection{Identified Case Studies}

After a review of the findings and other documentation that met $75 \%$ of the search terms within their title, abstract or keywords $(n=65), 11$ cases were qualified that fulfilled the inclusion criteria described in the methodology. A categorization of these cases was carried out and is summarized in Table 1. 
Table 1. Summary of the 11 cases considered for the review.

\begin{tabular}{|c|c|c|c|c|}
\hline Category & Quantity & Title & Study Area & Reference \\
\hline \multirow{4}{*}{ Case Study } & \multirow{4}{*}{4} & $\begin{array}{c}\text { The Potential of Small-Scale Biogas Digesters to Alleviate Poverty and Improve Long Term } \\
\text { Sustainability of Ecosystem Services in Sub-Saharan Africa }\end{array}$ & Debre Zeit, Ethiopia & [33] \\
\hline & & The Role of Low-cost Plastic Tube Biodigesters in Integrated Farming Systems in Vietnam & $\begin{array}{l}\text { Thuan An District, } \\
\text { Vietnam }\end{array}$ & [34] \\
\hline & & Biogas Plants for Farmers in Kenya: Case study of SuSanA Projects & Nairobi, Kenya & [21] \\
\hline & & $\begin{array}{l}\text { Small-Scale Biogas Facilities to Enhance Nutrient Flows in Rural Africa-Relevance, } \\
\text { Acceptance, and Implementation Challenges in Ethiopia }\end{array}$ & Arsi, Ethiopia & [35] \\
\hline \multirow{2}{*}{ Literature Review } & \multirow{2}{*}{2} & Overview of Holistic Application of Biogas for Small Scale Farmers in Sub-Saharan Africa & Sub-Saharan Africa & [36] \\
\hline & & Biogas Plants for Small Farms in Kenya & Kenya & [37] \\
\hline \multirow{2}{*}{$\begin{array}{l}\text { Dissertation and } \\
\text { Master Thesis }\end{array}$} & \multirow{2}{*}{2} & Quality and Usage of Biogas Digesters in Uganda & Uganda & [38] \\
\hline & & Environmental Sustainability of Floating Biodigesters in Tonlé Sap, Cambodia & Tonle Sap, Cambodia & [39] \\
\hline \multirow{2}{*}{ Project Report } & \multirow{2}{*}{3} & Floating Bio-digester for Integrated Waste Management in Agriculture and Energy Production & $\begin{array}{l}\text { Tonle Sap lake and its surrounding area, } \\
\text { Cambodia }\end{array}$ & [40] \\
\hline & & PRC: Efficient Utilization of Agricultural Wastes Project & Human, Hubei, Shanxi, Jiangxi, China & [41] \\
\hline
\end{tabular}


The majority of the case studies in Table 1 shortlisted for use in this review formed a small part of a comprehensive peer-reviewed publication (such as Smith et al. [33] wherein the Debre Zeit study area was the only relevant case for the purpose of this review). Such observations confirmed the lack of available literature evaluating rural closed-loop technology, reinforcing the need for research in this field.

In general, each of the case studies could not be said to be of the same quality and worth to the review; some of them consisted of more relevant information than others and the distinction between peer-reviewed and non-peer-reviewed literature was often clear.

The chosen studies cover a range of LMICs across three different continents (Asia, Africa, and Latin America), displaying a distinctly international nature of not only the review, but also the water-waste-energy-food model in rural agriculture. Figure 2 maps out the locations of the cases studied. Of the 11 studies, eight were location-specific. One study focused on a region (Sub-Saharan Africa) and two on individual countries (Kenya and Uganda).

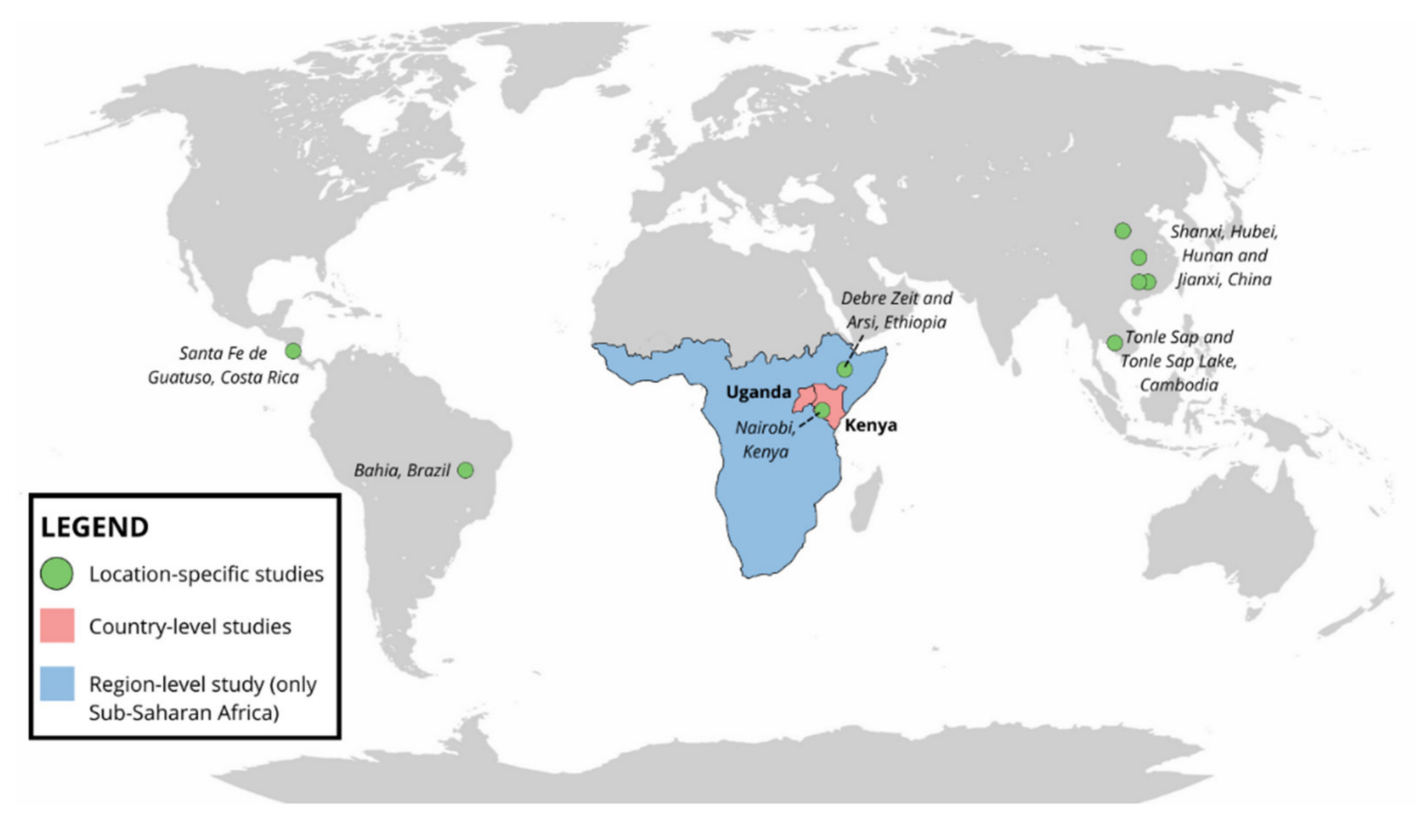

Figure 2. Locations of the 11 case studies identified for review.

Finally, the data extracted from the case studies regarding the previously established parameters can be found in Table 2. In the case of the reviews used within the analysis, the recommendations made in the articles and/or the responses of the majority were used. 
Table 2. Data extracted from case studies for review.

\begin{tabular}{|c|c|c|c|c|c|c|c|}
\hline No. & Reference & $\begin{array}{l}\text { Country/ } \\
\text { Region }\end{array}$ & Specifications & Costing & $\begin{array}{c}\text { Feedstock \& } \\
\text { Pre-Treatment }\end{array}$ & $\begin{array}{c}\text { Biogas } \\
\text { Management }\end{array}$ & $\begin{array}{c}\text { Digestate } \\
\text { Management }\end{array}$ \\
\hline 1 & [37] & Kenya & $\begin{array}{l}\text { Sasse floating drum design } \\
\qquad\left(6.2 \mathrm{~m}^{3}\right)\end{array}$ & $\begin{array}{l}15,200 \text { Kenyan } \\
\text { shillings (USD } 150) \\
\text { payback period of } 3 \\
\text { years }\end{array}$ & $\begin{array}{l}\text { Dry and fresh dairy manure (latter } \\
\text { observed to produce more methane); } \\
\text { collection using a trench or an earth } \\
\text { holding pen }\end{array}$ & $\begin{array}{l}\text { Cooking and lighting; } \\
\text { less frequently, } \\
\text { heating }\end{array}$ & $\begin{array}{l}\text { Used as bio-fertilizer for organic } \\
\text { farm crops }\end{array}$ \\
\hline 2 & [41] & China & $\begin{array}{l}\text { Fixed concrete dome } \\
\text { digester (generally } 8 \mathrm{~m}^{3} \text { ); } \\
\text { pigsty and latrines built } \\
\text { directly atop the digester } \\
\text { such that waste can be } \\
\text { channeled straight to the } \\
\text { fermentation chamber. }\end{array}$ & $\begin{array}{l}\text { Varies between USD } \\
440 \text { and USD } 560 \\
\text { depending on size } \\
\text { and features }\end{array}$ & $\begin{array}{c}\text { Pig and human waste; water stirred in } \\
\text { frequently to form slurry; often, this } \\
\text { water has been collected via rainwater } \\
\text { harvesting. }\end{array}$ & $\begin{array}{l}\text { Available at the point } \\
\text { of use for cooking; } \\
\text { remaining biogas is } \\
\text { used to heat the } \\
\text { greenhouse using gas } \\
\text { lamps }\end{array}$ & $\begin{array}{l}\text { Digestate used as fertilizer in the } \\
\text { greenhouse to grow organic } \\
\text { vegetables such as tomatoes }\end{array}$ \\
\hline 3 & [33] & Ethiopia & $\begin{array}{l}\text { Fixed dome Sinidu model } \\
\text { GGC 2047; 20-25 years } \\
\text { design life }\end{array}$ & $\begin{array}{l}\text { Owners only } \\
\text { responsible for local } \\
\text { materials and labor } \\
(\sim \text { USD } 66 \text { per farm }) \\
\text { which forms } 43 \% \text { of } \\
\text { the total cost } \\
\quad(\sim \text { USD } 155)\end{array}$ & $\begin{array}{l}\text { Cattle dung; if human waste is mixed in, } \\
\text { more biogas is produced but less } \\
\text { proportion of digestate present. Slurry } \\
\text { mixed by a stick in a digest inlet before } \\
\text { releasing a plug to allow flow into } \\
\text { digester; solid materials removed by } \\
\text { hand. Water obtained using a borehole. }\end{array}$ & $\begin{array}{l}\text { Mostly used for } \\
\text { lighting and cooking }\end{array}$ & $\begin{array}{l}\text { Allowed to flow out along } \\
\text { channels leading into a compost } \\
\text { heap; composted with dry } \\
\text { organic wastes from cattle pens } \\
\text { and crop residue generally at the } \\
\text { end of the growing season. } \\
\text { Larvae of rose chafer bugs also } \\
\text { help decompose } \\
\text { organic material. }\end{array}$ \\
\hline 4 & [38] & Uganda & $\begin{array}{l}\text { Majorly fixed dome } \\
\text { digesters (easiest to } \\
\text { construct, maintain and } \\
\text { most reliable) }\end{array}$ & $\begin{array}{l}6 \mathrm{~m}^{3} \text { fixed dome } \\
\text { digester costs ranged } \\
\text { between USD } 1000 \\
\text { and USD } 2000\end{array}$ & $\begin{array}{l}97 \% \text { of digesters surveyed used fresh cow } \\
\text { dung as feedstock; slurry was } \\
\text { mechanically stirred with a stick regularly } \\
\text { to avoid hardening. }\end{array}$ & $\begin{array}{l}\text { Piping with no more } \\
\text { than } 3 \text { bends/elbows } \\
\text { and no more than } 20 \\
\mathrm{~m} \text { from gas } \\
\text { destination for } \\
\text { minimum pressure } \\
\text { losses. Used for } \\
\text { cooking and lighting. }\end{array}$ & $\begin{array}{l}\text { Slurry largely used directly as } \\
\text { fertilizer to grow matooke, } \\
\text { vegetables, cereals and } \\
\text { root crops }\end{array}$ \\
\hline
\end{tabular}


Table 2. Cont.

\begin{tabular}{|c|c|c|c|c|c|c|c|}
\hline No. & Reference & $\begin{array}{l}\text { Country/ } \\
\text { Region }\end{array}$ & Specifications & Costing & $\begin{array}{l}\text { Feedstock \& } \\
\text { Pre-Treatment }\end{array}$ & $\begin{array}{c}\text { Biogas } \\
\text { Management }\end{array}$ & $\begin{array}{c}\text { Digestate } \\
\text { Management }\end{array}$ \\
\hline 5 & {$[36]$} & $\begin{array}{l}\text { Sub-Saharan } \\
\text { Africa }\end{array}$ & $\begin{array}{l}\text { If maintenance of optimal } \\
\text { temperature required, } \\
\text { fixed dome or floating } \\
\text { drum digester is preferable } \\
\text { to flexible balloon digester. }\end{array}$ & $\begin{array}{l}\text { Prices can vary from } \\
\text { about USD } 100 \text { to } \\
\text { USD 2000. Cheapest } \\
\text { designs are balloon } \\
\text { digesters but are also } \\
\text { most vulnerable to } \\
\text { accidental damage. }\end{array}$ & $\begin{array}{l}\text { Generally, excreta from livestock (e.g., } \\
\text { cattle, sheep, goats, horses, donkeys, } \\
\text { rabbits, chickens); human waste used if } \\
\text { culturally acceptable. Greenhouse canopy } \\
\text { may be used to raise the temperature in a } \\
\text { plastic digester; compost can be used for } \\
\text { insulation, or the biogas produced can } \\
\text { generate heat required. If water is } \\
\text { limiting, recycling water from household } \\
\text { uses or prior to use in irrigation is } \\
\text { suggested; household rainwater } \\
\text { harvesting may also be used. }\end{array}$ & $\begin{array}{l}\text { Yield is variable, } \\
\text { depending on } \\
\text { feedstock. Biogas } \\
\text { produced may be } \\
\text { used to generate heat } \\
\text { for the digester. }\end{array}$ & $\begin{array}{l}\text { Directly used to fertilize plants } \\
\text { and grow nutrient hungry cash } \\
\text { crops; or, used as manure } \\
\text { following composting with } \\
\text { other organic material such as } \\
\text { bagasse from sugarcane. }\end{array}$ \\
\hline 6 & {$[34]$} & Vietnam & $\begin{array}{l}\text { Polyethylene tube digester } \\
(\text { estimated volume of } \\
\left.5.1 \mathrm{~m}^{3}\right) \text {; floated in ponds to } \\
\text { avoid spatial constraints. }\end{array}$ & $\begin{array}{l}\text { USD } 35 \text { per unit; } \\
\text { USD } 15 \text { required to } \\
\text { change the plastic } \\
\text { film if damaged due } \\
\text { to the sun }\end{array}$ & Farm animal manure & $\begin{array}{l}\text { Primarily used } \\
\text { for cooking }\end{array}$ & $\begin{array}{c}\text { Slurry used to grow Lilium } \\
\text { flower, elephant grass and } \\
\text { sweet potato }\end{array}$ \\
\hline 7 & {$[42]$} & $\begin{array}{l}\text { Costa Rica } \\
\text { and Brazil }\end{array}$ & $\begin{array}{c}\text { Costa Rica: Polyethylene } \\
\text { tube digester }(1.9 \mathrm{~m} \times \\
1.5 \mathrm{~m} \times 3.0 \mathrm{~m} \text { long); } \\
\text { construction time is one } \\
\text { week. Mixture ratios of } \\
\text { manure and water is } 40 \mathrm{~L} \\
\text { per } 20 \mathrm{~L} . \\
\text { Brazil: Small-scale } \\
\text { biodigesters (covered } \\
\text { digester) }\end{array}$ & $\begin{array}{l}\text { Costa Rica: USD } 700 \\
\text { per digester. } \\
\text { Brazil: USD } 300 \text { per } \\
\text { biodigester }\end{array}$ & $\begin{array}{l}\text { Cow and pig manure from surrounding } \\
\text { farms; also, goat manure }\end{array}$ & $\begin{array}{l}\text { Used as fuel for } \\
\text { appliances. The main } \\
\text { use is for cooking } \\
\text { stoves in place of } \\
\text { wood burning; also, } \\
\text { use for lighting } \\
\text { and cooking }\end{array}$ & $\begin{array}{l}\text { Used in agriculture as } \\
\text { organic fertilizer }\end{array}$ \\
\hline 8 & {$[21]$} & Kenya & $\begin{array}{l}\text { Fixed dome digesters }(12 \\
\times 16 \mathrm{~m}^{3} \text { in operation, } 8 \\
\text { further planned) }\end{array}$ & $\begin{array}{l}\text { USD } 1500 \text { for each } 16 \\
\mathrm{~m}^{3} \text { digester; average } \\
\text { investment of about } \\
\text { USD } 80-100 \text { per } \mathrm{m}^{3} \\
\text { digester volume. }\end{array}$ & $\begin{array}{l}\text { Mainly animal manure and biowaste. } \\
\text { First digesters combined with latrines; } \\
\text { pretreatment of organic waste with } \\
\text { unfavorable pH or high or low moisture } \\
\text { content. }\end{array}$ & $\begin{array}{l}\text { Captured and } \\
\text { conducted by pipes } \\
\text { to adapted stove and } \\
\text { pressure lamps; } \\
\text { stored in the dome. }\end{array}$ & $\begin{array}{l}\text { Slurry of digester used as } \\
\text { fertilizer. }\end{array}$ \\
\hline
\end{tabular}


Table 2. Cont.

\begin{tabular}{|c|c|c|c|c|c|c|c|}
\hline No. & Reference & $\begin{array}{l}\text { Country/ } \\
\text { Region }\end{array}$ & Specifications & Costing & $\begin{array}{c}\text { Feedstock \& } \\
\text { Pre-Treatment }\end{array}$ & $\begin{array}{c}\text { Biogas } \\
\text { Management }\end{array}$ & $\begin{array}{c}\text { Digestate } \\
\text { Management }\end{array}$ \\
\hline 9 & [40] & Cambodia & $\begin{array}{c}\text { Floating drum gas } \\
\text { reservoirs }-4 \text { soft plastic } \\
\text { biodigesters of } 2 \times 500 \mathrm{~L} \text {, } \\
1 \times 1000 \mathrm{~L}, 1 \times 1500 \mathrm{~L} ; \\
3 \text { hard plastic biodigesters: } \\
3 \times 500 \mathrm{~L} \text {; wooden and } \\
\text { bamboo floating frames; } \\
\text { flexible piping }\end{array}$ & $\begin{array}{l}\text { Low cost of materials; } \\
\text { self-adapted system }\end{array}$ & $\begin{array}{l}\text { Biodigesters are fed daily with one of the } \\
\text { three feedstocks: pig waste and water, pig } \\
\text { waste and water hyacinth (Eichhornia } \\
\text { Crassipes), or pig waste, human waste } \\
\text { and household waste }\end{array}$ & $\begin{array}{l}\text { Parameters are being } \\
\text { tested: daily } \\
\text { measurements of gas } \\
\text { production; methane } \\
\text { content of the gas } \\
\text { produced }\end{array}$ & $\begin{array}{l}\text { Parameters are being tested: } \\
\text { Pathogen reduction of the feed } \\
\text { wastes; bio-digested waste } \\
\text { nutrient content. }\end{array}$ \\
\hline
\end{tabular}

Hard plastic HDPE, 200 L

to 2000 L. Problem with

clogging in- and outlets; to avoid it, improvements such as using a baffled wall inside the digester to change the flow direction. Soft plastic tube digesters; easily scalable. Largest tubular biodigester installed so far is $4000 \mathrm{~L}$. Also installed simple recycled tractor tire digestor connected to PVC-pipes for inlets and outlets (tires also are used for gas collection)

The hard-plastic dome biodigester is cost-effective for biodigester vessels (due to less manufacturing available); soft plastic digester has low investment costs and easy maintenance
Use of human waste, pig manure and water hyacinth; co-digestion of water hyacinth with human waste and manure beneficial, balance the overall $\mathrm{C}$ : N ratio to optimum levels. For people without access to pig manure, co-digestion of human waste and water hyacinth can be suitable for biogas production.
Used in cooking stoves to replace fuel wood.
Fertilizer for floating gardens, farmlands.
Fixed dome digesters, $6 \mathrm{~m}^{2}$ or $9 \mathrm{~m}^{2}$ depending on number of cows owned.
No data available.

\section{Cow manure (on average $31 \mathrm{~kg}$ per day);} human waste (on $75 \%$ of the farms)
Used for biogas lamp

(by $54 \%$

used for stove

(by $98 \%$ farmers)
Bioslurry used as fertiliser applied to crops directly or transferred into a bioslurry compost. Some issues exist with overflow and impurities in bioslurry 


\subsection{Insights from Case Studies}

\subsubsection{Specifications of Rural Digesters}

Each of the documents reviewed (Tables 1 and 2) provides insight regarding the $\mathrm{AD}$ digesters used in small-scale rural systems. These are either based on the fixed biogas dome or the floating drum design, although the tubular flexible balloon model is mentioned as an inexpensive alternative.

Hojnacki et al. [42] report on biodigesters from gathered data of 80 different case studies of biodigesters located in five different parts of the globe, including China, Brazil, Central America (Costa Rica and Honduras), and India. From all 80 case studies reported by the authors, only two contain information about small-scale digesters, which are one example from Costa Rica (Santa Fe de Guatuso) and one from Brazil (Bahia). They provide a broad understanding of the technology of types of biodigesters in terms of size, construction, supply, model, and usage (Tables 1 and 2).

Nijaguna [43] points out three main designs for the most used rural digesters, which are in decreasing order, the fixed dome, the floating cover and the bag-tube type. Gensch [21] shows biogas usage for adapted stove and pressure lamps (modified to biogas). Biogas is directly used or stored in the dome. Maintenance entails the proper care of water traps, gas burners and lamps. The emerging biogas is led through metal or plastic pipes to the point of use or collected in the upper part of the biogas digestor (dome) for storage purposes (gas holder). From there it is led to the point of use (burner or lamp) by pipes. Gas piping is simply either galvanized pipes or plastic pipes with rubber hose for final connection to point of use.

Biodigesters in floating villages is a novel topic, since biodigesters in rural areas have mainly been land-based. Small-scale AD using only human waste as input has not been widely evaluated. Biodigesters using exclusively human waste will not be enough to produce sufficient gas amounts for a household. In these cases, a small-scale biodigester could be additionally fed with livestock manure. A high amount of nitrogen (from the breakdown of proteins) is in human waste which requires additional carbon input to prevent ammonia inhibition in the methanogens. Urea contains ammonia and should be mixed with substrates with high C:N ratio such as straw [39].

Buntha et al. [40] present a combined flexible-hard digester system. Live and Learn Environmental Education Cambodia are working in partnership with the Royal University of Agriculture and Engineers Without Borders Australia about integrated food production and sanitation for floating communities. They provide development and application of a low-cost system, integrating different soft plastic tubular and hard plastic digesters connected with a contracted floating drum reservoir, which collect the generated biogas. This system can be suitable for tropical rainy areas with a low cost for the adapted materials and easily integrated for animal and human wastes.

Floating biodigesters suitable for water sanitation as well as renewable energy production are examples provided by Buntha et al. [40] and Carlsson and Kiste [39]. In these cases, the feeds to the biodigester are mainly pig manure and human excrement. Therefore, direct pollution to the water is reduced since the waste products are used as a resource instead. As a by-product, methane in biogas is available for household usages. It mitigates burning wood for cooking which causes health problems as well as deforestation.

A fixed dome digester, such as the Sinidu model GGC 2047 [33], consists of a dome atop a fermentation tank, both constructed of concrete underground. The gas is stored in the upper part of the digester. Once gas production commences, the slurry in the digestion tank overflows into the outlet tank. The biogas is available for collection at the top of the fixed dome [44]. Fixed domes may also be masonry structures, and ferrocement structures exist as well-specifications generally depend on local availability of materials and skilled labour, both of which directly influence the cost of the system $[45,46]$. A major disadvantage of this system is its fluctuating gas pressure and the need of highly skilled technicians for initial installation. Figure 3a shows a fixed dome digester sketch [34]. It should be noted 
that if fixed dome digesters are used, the materials and construction must be of high quality to avoid biogas leakage.

A floating drum digester consists of a similar underground digester; however, a moving gas-holder (the "floating drum") takes the place of the fixed dome. The gas-holder floats either directly on the fermentation slurry or on a water jacket. This system makes it easy to determine the volume of the stored gas and provides gas of constant pressure [47]. Construction is relatively easy as well, but the costs of the steel drum are generally higher, as it is prone to corrosion and has a shorter design life than the fixed dome digester [48]. Figure $3 \mathrm{~b}$ depicts a typical simple floating drum model used in rural areas across the world.

A flexible balloon (or tubular) digester is considered an inexpensive alternative to floating drum and fixed dome digesters [34,49]. Low-cost tubular digesters generally consist of a sheet of plastic, either low-density polyethylene (LDPE), high-density polyethylene (HDPE) or polyvinyl chloride (PVC). They are, hence, flexible, taking the shape of the container they are installed in [50]. The feedstock is input into the digester from an inlet at one end, and the balloon-like chamber separates the gas from the slurry to be collected from the outlets. See the schematic of a tubular digester in Figure 3c [51].



(a)

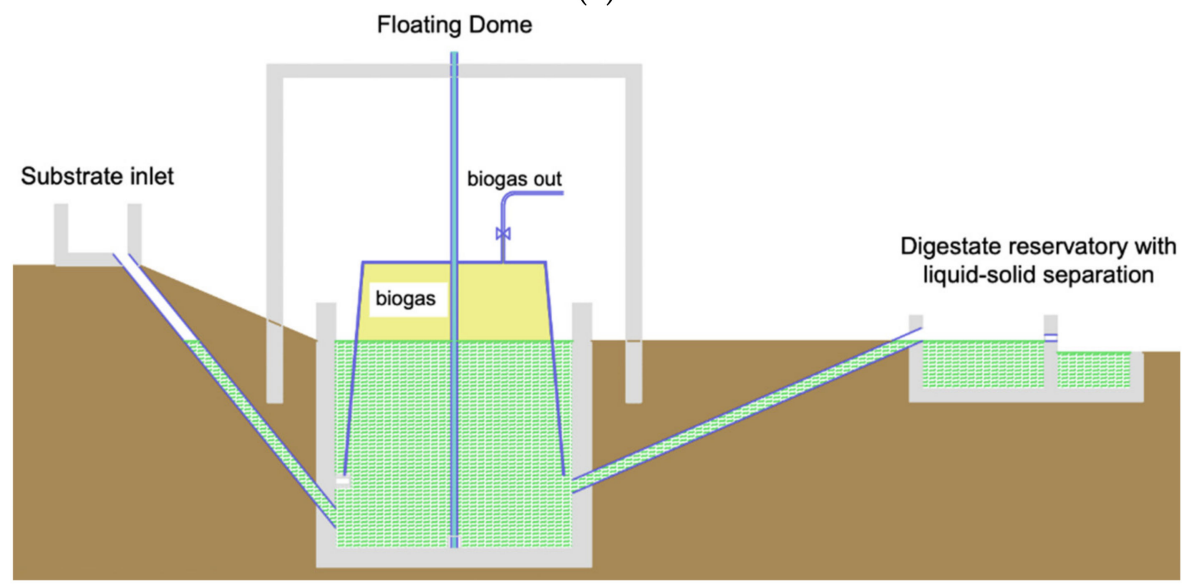

(b)

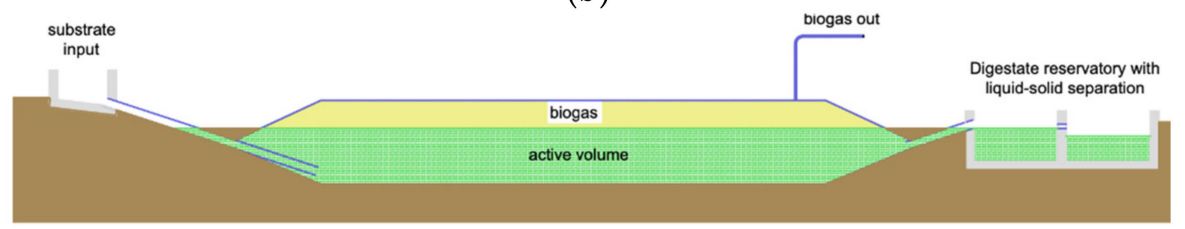

(c)

Figure 3. Schematics of prevalent types of digesters: (a) Fixed dome, a gas-tight chamber constructed of bricks, stone or poured concrete (modified from An et al. [52]); (b) Sasse floating drum model (modified from Zang et al. [51]) (c) tubular (flexible balloon) digester (modified from Zang et al. [51]). 
The AD biodigester schematics of Figure 3 shows examples of very adaptable units for farming families in LMICs. The AD type should take into consideration the number of individuals on the family farm (human waste), their animal manure forms, and types of agricultural wastes (various residual feedstocks available in the surrounding areas) should be taken into consideration. Rowse shows a village-sized fixed dome AD digester of $48.4 \mathrm{~m}^{3}$ for 48 households, fed with the manure of two swine-gestating sows, six swine-boars, 170 poultry, 20 cattle-beef, two dairy cattle, would generate in a fixed dome AD digester 43.5 $\mathrm{m}^{3}$ of biogas per day [53]. If a family farmer requires for daily cooking $0.85 \mathrm{~m}^{3}$ biogas, the total of $43.5 \mathrm{~m}^{3}$ of biogas would cover 51 farming households [43]. The generated biogas values can be converted into specific biogas production rates by dividing the observed biogas values by the volatile solids (VS) reduction, which gives the biogas volume of $\mathrm{m}^{3}$ of biogas per $\mathrm{kg}$ VS reduced or converted by the AD process.

Table 3 compares fixed dome, floating drum and flexible tubular balloon digesters across a range of parameters such as materials, cost, construction times and maintenance requirements. This comparison confirms that while flexible balloon (or tubular) digesters are inexpensive and much more affordable than the alternative, they may have a less predictable design life which may be shortened severely with high exposure to the sun.

Table 3. Characteristic comparison of fixed dome, floating drum and flexible balloon digesters.

\begin{tabular}{|c|c|c|c|}
\hline & Fixed Dome & Floating Drum & Flexible Balloon \\
\hline Investment Costs & $\begin{array}{l}\text { As much as USD } 1400 . \\
\text { Between USD } 80 \text { and } 100 \text { per } \\
\mathrm{m}^{3} \text { per digester volume in } \\
\text { Nairobi, Kenya }\end{array}$ & $\begin{array}{l}\text { Between USD } 800 \text { and } \\
\text { USD } 1700\end{array}$ & $\begin{array}{l}\text { Between USD } 140 \text { and USD } \\
215 \text { in Ecuador/Costa Rica; } \\
\text { between USD } 180 \text { and USD } \\
340 \text { in Vietnam }\end{array}$ \\
\hline Construction Skill Required & $\begin{array}{l}\text { High construction } \\
\text { skills required }\end{array}$ & $\begin{array}{l}\text { Medium to high construction } \\
\text { skills required }\end{array}$ & $\begin{array}{l}\text { Medium construction } \\
\text { skills required }\end{array}$ \\
\hline Material Quality Required & $\begin{array}{l}\text { High quality } \\
\text { materials required }\end{array}$ & $\begin{array}{l}\text { High quality } \\
\text { materials required }\end{array}$ & $\begin{array}{l}\text { Medium quality } \\
\text { materials required }\end{array}$ \\
\hline Construction Time & 18 days & 18 days & 2 days \\
\hline $\begin{array}{l}\text { Operations and Maintenance } \\
\text { Skill Required }\end{array}$ & $\begin{array}{l}\text { High level of skill required to } \\
\text { check for gas leaks }\end{array}$ & High level of skill required & $\begin{array}{l}\text { Medium level of } \\
\text { skills required }\end{array}$ \\
\hline Design Life & 20 years & 15 years & 2 years if exposed to the sun \\
\hline Temperature Maintenance & $\begin{array}{c}\text { Underground, thus largely } \\
\text { unaffected by } \\
\text { temperature variation }\end{array}$ & $\begin{array}{l}\text { Only works in warm } \\
\text { conditions and requires } \\
\text { external heating }\end{array}$ & $\begin{array}{l}\text { Heated easily due to } \\
\text { thin walls }\end{array}$ \\
\hline
\end{tabular}

\subsubsection{Costs}

While system costs depend on the specifications of the digester, in some of the cases, a large proportion of the expenses is borne by a sponsor rather than the owners themselves. These may be paid back over a previously agreed period of time [37,41]. In the case of Buntha et al., they saved costs by means of a low-cost system that includes soft and hard plastic biodigesters connected to a hard-plastic floating drum reservoir and bamboo to sustain the system [40]. A common kitchen in small communities could save costs jointly in a small cluster by using biogas distributed from the biogas storage vessel through filling truck tire inner tubes or other small plastic reservoirs with biogas. Rowse, Buntha et al. and Gensch show some self-adapted systems for saving costs such as biogas adapted stoves and lamps $[21,40,53]$.

\subsubsection{Feedstock and Pre-Treatment}

Animal excreta is generally used as feedstock for the biodigester, though human excreta may also be mixed for AD co-digestion depending on social acceptability. Smith et al. observed that human waste improved the quantity of biogas produced, but the 
proportion of useful digestate reduced [33]. Additionally, Day et al. reported that fresh excreta tended to produce more methane than dry excreta [37]. Hojnacki et al. shows a unique covered $\mathrm{AD}$ system for the recovery of energy and nutrients from goat manure in Brazil [42].

The cases presented by the Asian Development Bank operate the Chinese four-inone model to collect feedstock, which aims to combine the collection of pig and human excreta and channel it into a biodigester, from which digestate generated is used within a greenhouse [41]. This approach demonstrates a compact, holistic arrangement for small scale farming that can be replicated for the incorporation of a greenhouse. Although feedstock does not seem to be pre-treated before input, water is stirred in frequently (either by hand or using a stick) to form a uniform slurry devoid of large solid particles. This water may be obtained using a borehole or through rainwater harvesting.

In the floating system of Buntha et al., hard and soft plastic biodigesters convert in co-digestion mixtures human and animal waste from floating pig farms, and water hyacinth plants that grow abundant in Asian lakes into biogas for energy, and to treat waste for agriculture or fish feed [40].

Carlsson and Kiste [39] show biodigesters in floating areas using similar AD-feedstocks as Buntha et al. [40] examples, but they also make remarks about using rice field waste and cow dung to provide biogas generation. The idea of a cluster of households for enhancing biogas generation through feeding an AD digester system with the community waste of animals is interesting. For example, to save costs and to share operations and maintenance $(\mathrm{O}$ and $\mathrm{M}), 3.0 \mathrm{~m}^{3}$ biodigesters (polyethylene tubular or floating drum) were designed for animal waste from six households in India. These digesters were fed with manure of two swine, 25 poultry and one cattle-beef and generated daily $2.7 \mathrm{~m}^{3}$ biogas, which corresponds to half of the energy needs of six family households [53].

Schoeber et al. recommends forage legumes, shrubs, and hybrid grasses be added to feedstock to raise its quality. Furthermore, it suggests that use of organic material such as vegetable residue and other types of manure might increase bio-slurry production [35]. However, most cases studied argue that input of human excreta in the digester improves biogas production as opposed to the input of animal excreta or organic waste. Thus, this is contradictory to Venugopalan et al. who observed that the difference between the yield with human excreta, food waste and organic wastes was not significant [54]. A strong inference hence cannot be drawn regarding feedstock.

Regarding the required ratio by which to measure manure and water inputs, MartiHerrero et al. [55] has studied it to be 1:1 manure: water for fixed dome digesters and 1:3 for tubular digesters.

\subsubsection{Biogas Management}

Generally, biogas was sent via pipeline to farmers' households in order to be used for cooking and lighting within them. In two cases, the biogas was also applied for heating either the households or the greenhouse that supplemented the farm. Gensch [21] gives attention to biogas-adapted stoves and lamps, and the biogas is also captured by pipes.

Orskov et al. suggested that the biogas generated (or at least part of it) could be used to maintain the required ambient temperature for the biodigester [36]. Yield was indicated to be variable. In the system of Buntha et al. [40], floating hard-plastic reservoirs retain the biogas in wet areas.

\subsubsection{Digestate Management}

The case studies reviewed (Tables 1 and 2) suggest that no solid/liquid separation is carried out on the digestate; that is, the digestate remaining after the AD process is used to fertilize plants after dilution. In some cases, it is composted with dry organic waste to be used as bio-fertilizer for farming later. Biogas for energy and to treat waste for agriculture and fish feed is presented by Buntha et al. [40]. 


\subsection{Recommendations}

Adaptations in design for flexible digesters may offer options to protect plastic or rubber materials from the sunlight, e.g., in the case of land, burying it halfway into the ground, and in the case of floating areas, covering the digesters with bamboo or wood materials.

As $\mathrm{AD}$ is a temperature-dependent process, the variance of the ambient temperature can cause large fluctuations in the productivity and efficiency of the digester [56]. This introduces the need for temperature control. From this perspective, the fixed dome design may be optimal for a farm-scale biodigester in a location where climate poses a problem. Alternatively, greenhouse canopies may be used to maintain the required ambient temperature as suggested in Orskov et al. [36].

Co-digestion of animal manures with industrial organic wastes or energy crops has been studied to enhance farm-scale biogas production [57]. Waste like agricultural straw, however, must be pre-treated prior to digestion [58]. Composting pre-treatment is an environmentally friendly method of improving $\mathrm{AD}$ productivity and, therefore, co-digestion with it could be the ideal way of optimizing a small farm-scale AD system in LMICs.

The cases analyzed within this review indicate that most, if not all, of the biogas produced in the $\mathrm{AD}$ process is used for household purposes such as cooking, lighting and heating. It has also been suggested that some of the biogas be used to generate heat for the biodigester if needed [36]. However, it is possible to use the gas for farm purposes such as motor fuel or in a generator [59]. In addition, biogas upgrading, and bottling has been reported to be a viable alternative to compressed natural gas $(\mathrm{CNG})$ in vehicles through the use of gas kits [60]. If biogas can be used for both on-farm vehicles and electricity generation successfully, such a system could reinforce the closed-loop in small-scale farms and create a more sustainable local economy. This method has been implemented successfully in Indiana, USA, reducing diesel costs and creating a revenue stream for excess electricity. However, the 35,000-cow dairy farm in this case had government support of over USD 12 million and the benefit of scale, thus may not be directly transferrable for the case of small LMIC farms [61].

Although the cases reviewed (Tables 2 and 3) note direct usage of digestate on crops as fertilizer, the health and sanitation aspects of such a practice can be called into question, especially with regards to digestate from human waste [62]. Rain events may also lead to digestate directly applied to land losing its nutrient content and polluting local water bodies. As such, bio-slurry may be dried in the sun; however, this may result in almost total loss of inorganic nitrogen [63]. Therefore, it can be recommended that instead of direct application, bio-slurry be composted prior to use as fertilizer [64]. This reduces, if not eliminates, the health and safety risk posed by pathogens in liquid bio-slurry, while retaining its nutrient content $[65,66]$. Another alternative to direct application is the use of a struvite $\left(\mathrm{MgNH}_{4} \mathrm{PO}_{4}\right)$ precipitation reactor for nitrogen and phosphorous recovery. $\mathrm{A}$ pilot-scale demonstration of creating this struvite fertilizer as a part of a small-scale AD system was conducted in Costa Rica with promising results [67]. The reactor was relatively low-cost (USD 660) and made using locally available virgin and second-life materials.

Many closed-loop pilots have utilized wastewater treatment practices such as the use of constructed wetlands (CW) to separate the liquid fraction of the digestate for utility in the $\mathrm{AD}$ system [62]. However, a constructed form can be expensive for small-scale systems of rural farms. Alternatives for treating AD digestate could be aquatic plants and macrophytes filtering gardens [68]. For example, a study from Indonesia using Canna indica, Iris pseudacorus, and Typha latifolia to uptake nutrients from digestate found that highest $\mathrm{N}$ uptake and biomass increment were carried out by Canna indica $(25.1 \%$ and $80.5 \%$, respectively) [69]. In addition, effluent $\mathrm{N}$ removal was also achieved by Canna indica (68.5-76.4\% total nitrogen-TN), Iris pseudacorus (61.8-71.3\% TN), and Typha latifolia $(61.6-74.5 \% \mathrm{TN})$. 


\subsection{Analysis of the Review Methodology}

This study reviewed literature and compared case studies regarding closed-loop AD technologies for rural communities, utilizing databases and search engines for this purpose. The geographical locations, system designs, operation and maintenance procedures, and economic implications were extracted, compared, and discussed.

While efforts were taken to ensure thoroughness and exhaustiveness of the review, it is possible for sources to have been overlooked. For example, though the databases searched were international, they may not have contained articles from regional journals published in LMICs, or articles chosen may have been a target to publication biases.

The inclusion of literatures such as a dissertation, a master thesis [38], and a project report [41] created a larger pool to extract valuable pictures and data from, rather than the use of only journal articles. This can alternatively be said to have diluted the quality of the review slightly; however, the scale of this cannot be exactly pinpointed. Regardless, the use of predominantly peer-reviewed literature has maintained a good standard of quality of the review.

Conversely, the use of largely peer-reviewed literature can be observed to have adversely impacted the range of cases studied. It is possible that upon inclusion of perhaps less reliable data, more elaborate and thorough case studies may have been located. As it stands, not only is the data reviewed too limited to draw strong conclusions from, but it is also rather varied in scope. For example, studies touching upon data generalized across an abstract area such as Sub-Saharan Africa [36] can arguably not be used in conjunction with an article concerning only a specific district in Vietnam [34].

In addition, in some cases the data has been extracted from isolated cases [33] which may not be wholly representative of actual conditions. Due to the small sample size, inferences thus drawn may not be accurate. Finally, some studies used $[34,37]$ and the information therein may no longer be considered relevant due to their age.

Overall, while this review encompasses technology located in a number of LMICs (e.g., Kenya, Uganda, Ethiopia, China, Cambodia, Brazil, Costa Rica) and covers a variety of arguments regarding farm-scale biodigester technology from different viewpoints, it points to a clear lack of research, data, and reporting in this field. It is evident that while progress is being made in LMICs to adapt closed-loop of water-waste-energy-food (WWEF) systems to the local climate, economy and sociocultural environment, the documentation to support this is largely absent.

\subsection{Future Research Opportunities}

There is a clear lack of published research and case studies that document small-scale closed-loop systems, as highlighted earlier. Given the benefits of anaerobic digestion on smallholder farms, there will be a need to validate the specification recommendations highlighted in this paper. Therefore, further research that investigates this topic in different geographies and evaluates the effectiveness of recommendations provided will be beneficial. Settings that are not small-scale rural farms but may be close comparisons to make, such as urban community farms and markets, could also be considered, with contextual differences accounted for.

Furthermore, in the future, there could be consideration given to technological advancements in the past few years, leading to the classification of existing literature by the publication period; innovations in low-cost materials can be accounted for here. Including sociocultural parameters such as local ownership and indigenous practices might also be an integral area of work. Gaps in local knowledge for implementing AD systems must be studied in order to develop better educational material and more effective participatory programs for small-scale farms.

Simultaneously, it will be important to look at long-term financial sustainability and impact of small-scale farm AD systems, with or without incentives from governments. On environmental sustainability, given the potency of methane as a greenhouse gas (GHG), the GHG abatement potential of small-scale farm AD systems can also be studied. Indirect 
abatement of carbon dioxide emissions through the use of biogas and avoidance of synthetic fertilizer can form a part of this research.

\section{Conclusions}

This structured review aimed to assess and recommend closed-loop technologies for small-scale waste-water-energy-food systems focusing in small-scale farms in LMICs. The review shows that presently, the published literature in the AD sector focuses on household systems rather than on-farm closed-loop technology.

The anaerobic digesters used in small-scale rural systems are mostly based on the fixed biogas dome or the floating drum design, but the tubular flexible balloon model is mentioned as a low-cost alternative. Interestingly, in some of the cases reviewed, a large proportion of the design and construction expense is borne by a sponsor, with the owners themselves only bearing operational expenses. In addition, while progress is being made in LMICs to adapt closed-loop WWEF systems to the local climate, economy, and sociocultural environment, the review revealed that the documentation to support this is largely absent. This makes disseminating learnings from implemented projects even more important.

While case studies sourced from across the LMICs provide a direction to how closedloop AD-WWEF systems may be implemented in these farm-scale contexts, literature also suggests gaps at the macro-level. This includes incentives, skill-building, and the need for community buy-in to prime WWEF systems for success. Overall, there is an opportunity to test the technical parameters recommended in this review in the future. At the same time, researching and understanding financial sustainability and sociocultural parameters will also play an important role in closing the loop in organic farms and improving rural livelihoods.

Funding: This project was supported by the Institutional Links grant (Grant numbers 332266861 and 201710267001279), under the Newton Fund: Institutional Links programme between the United Kingdom and Brazil partnership. The grant is funded by the UK Department of Business, Energy and Industrial Strategy (BEIS) and the Brazilian State of Goiás Foundation-FAPEG for Supporting Research and delivered by the British Council. Some aspects of the research were supported by the Brazilian Research Council CNPq (Grant number 402721/2017-9).

Institutional Review Board Statement: Not applicable.

Informed Consent Statement: Not applicable.

Acknowledgments: The authors are grateful to Rene Van Der Velden for contributing to the initial drawings.

Conflicts of Interest: The authors declare no conflict of interest.

\section{References}

1. WHO \& FAO. Codex Alimentarius-Organically Produced Foods; Food and Agriculture Organization of the United Nations: Rome, Italy, 2007. Available online: http:/ / www.fao.org/3/a1385e/a1385e00.pdf (accessed on 1 October 2021).

2. Rundlöf, M.; Smith, H.; Birkhofer, K. Effects of Organic Farming on Biodiversity. 2016, pp. 1-7. Available online: https: //www.researchgate.net/publication/312334427_Effects_of_Organic_Farming_on_Biodiversity (accessed on 24 July 2021).

3. Leifeld, J.; Fuhrer, J. Organic farming and soil carbon sequestration: What do we really know about the benefits? Ambio 2010, 39, 585-599. [CrossRef]

4. Auerswald, K.; Kainz, M.; Fiener, P. Soil erosion potential of organic versus conventional farming evaluated by USLE modelling of cropping statistics for agricultural districts in Bavaria. Soil Use Manag. 2003, 19, 305-311. [CrossRef]

5. Gomiero, T.; Paoletti, M.G.; Pimentel, D. Energy and Environmental Issues in Organic and Conventional Agriculture. Crit. Rev. Plant Sci. 2008, 27, 239-254. [CrossRef]

6. Drinkwater, L.; Wagoner, P.; Sarrantonio, M.; Drinkwater, L.E.; Wagoner, P.; Sarrantonio, M. Legume-based cropping systems have reduced carbon and nitrogen losses. Nature 1998, 396, 262-265. [CrossRef]

7. The World of Organic Agriculture. Statistics and Emerging Trends 2021; Willer, H., Travnicek, J., Meier, C., Schlatter, B., Eds.; Research Institute of Organic Agriculture FiBL: Bonn, Germany, 2021.

8. Seufert, V. Organic Agriculture as an Opportunity for Sustainable Agricultural Development. Available online: https://www. mcgill.ca/isid/files/isid/pb_2012_13_seufert.pdf2013 (accessed on 24 July 2021). 
9. Food and Agricultural Organization of the United Nations (FAO). Organic Agriculture and Food Availability. In Proceedings of the International Conference on Organic Agriculture and Food Security, Rome, Italy, 3-5 May 2007.

10. Amigun, B.; Parawira, W.; Musango, J.K.; Aboyade, A.O.; Badmos, A.S. Anaerobic biogas generation for rural area energy provision in Africa. Biogas 2012, 36-62.

11. Davis, S.C.; Kauneckis, D.; Kruse, N.A.; Miller, K.E.; Zimmer, M.; Dabelko, G.D. Closing the loop: Integrative systems management of waste in food, energy, and water systems. J. Environ. Stud. Sci. 2016, 6, 11-24. [CrossRef]

12. Bond, T.; Templeton, M.R. History and future of domestic biogas plants in the developing world. Energy Sustain. Dev. 2011, 15, 347-354. [CrossRef]

13. Milanez, A.Y.; Guimarães, D.D.; Maia, G.B.D.S.; Souza, J.A.P.D.; Lemos, M.L.F. Biogas from agroindustrial wastes: Panorama and perspectives. Biogas 2018, 47, 221-276.

14. FNR. Fachagentur Nachwachsende Rohstoffe e.V. (FNR). Guia do Biogas. $5^{a}$ Edição, Totalmente Revista e atualizada; FNR: Guülzow, Germany, 2010; Available online: http:/ / www.limpezapublica.com.br/cartilhas/giz_-_guia_pratico_do_biogas_final.pdf (accessed on 1 October 2021).

15. Kunz, A.; Steinmetz, R.L.R.; Amaral, A.C.D. Fundamentos da Digestão Anaeróbia, Purificação do Biogás, Uso e Tratamento do Digestado; Embrapa Suínos e Aves: Concórdia, Brazil, 2019; 209p, ISBN 978-85-93823-01-5. Available online: http://www.alice.cnptia. embrapa.br/alice/handle/doc/1108617 (accessed on 22 September 2021).

16. Seixas, J.; Folle, S.; Marchetti, D. Construção e Funcionamento de Biodigestores; Brasília, DF: Embrapa, circular técnica n0 4, janeiro; CPAC: Brasília, Brazil, 1981.

17. CETEC. Fundação Centro Tecnológico de Minas Gerais. Estado da Arte da Digestão Anaerobia; CETEC: Belo Horizonte, Brazil, 1982; ISSN 0100-9540.

18. Vaneeckhaute, C.; Styles, D.; Prade, T.; Adams, P.; Thelin, G.; Rodhe, L.; Gunnarsson, I.; D’Hertefeldt, T. Closing nutrient loops through decentralized anaerobic digestion of organic residues in agricultural regions: A multi-dimensional sustainability assessment. Resour. Conserv. Recycl. 2018, 136, 110-117. [CrossRef]

19. Van der Velden, R.; Fonseca-Zang, W.; Zang, J.; Clyde-Smith, D.; Leandro, W.M.; Parikh, P.; Borrion, A.; Campos, L.C. Closed-loop organic waste management systems for family farmers in Brazil. Environ. Technol. 2021, 1-18. [CrossRef]

20. Balat, M.; Balat, H. Biogas as a Renewable Energy Source-A Review. Energy Sour. Part A Recover. Util. Environ. Eff. 2009, 31, 1280-1293. [CrossRef]

21. WELL. Using Human Waste (WELL Technical Briefs 63); WELL: Loughborough, England, 2010.

22. Gensch, R. Case Study of SuSanA Projects; Biogas plants for farmers in Kenya: Nairobi, Kenya, 2008.

23. Spuhler, D. Anaerobic Digestion (Small-Scale). 2010. Available online: http://archive.sswm.info/print/1182?tid=853 (accessed on 24 July 2021).

24. Ioannou-Ttofa, L.; Foteinis, S.; Moustafa, A.S.; Abdelsalam, E.; Samer, M.; Fatta-Kassinos, D. Life cycle assessment of household biogas production in Egypt: Influence of digester volume, biogas leakages, and digestate valorization as biofertilizer. J. Clean. Prod. 2020, 286, 125468. [CrossRef]

25. Pilloni, M.; Hamed, T.A. Small-Size Biogas Technology Applications for Rural Areas in the Context of Developing Countries [Online First], IntechOpen. 2021. Available online: https:/ / www.intechopen.com/online-first/75926 (accessed on 13 September 2021). [CrossRef]

26. Kilcher, L. How organic agriculture contributes to sustainable development. J. Agric. Res. Trop. Subtrop. Suppl. 2007, 89, 31-49.

27. Ministério das Cidades, Brasil. Secretaria Nacional de Saneamento Ambiental. Probiogás. Tecnologias de Digestão Anaeróbia com Relevância para o Brasil: Substratos, Digestores e Uso de Biogás/Probiogás; Organizadores: Deutsche Gesellschaft für Internationale Zusammenarbeit GmbH (GIZ); Ministério das Cidades: Brasília, Brazil, 2015; ISBN 978-85-7958-039-0.

28. Wang, J. Decentralized Biogas Technology of Anaerobic Digestion and Farm Ecosystem: Opportunities and Challenges. Front. Energy Res. 2014, 2. [CrossRef]

29. Werner, U.; Stoehr, U.; Hees, N. Biogas Plants in Animal Husbandry. 1998. Available online: https://sswm.info/sites/ default/files/reference_attachments/WERNER\%201989\%20Biogas\%20plants\%20in\%20Animal\%20Husbandry.pdf (accessed on 24 July 2021).

30. NCA. Lessons Learned from the Dissemination of Biodigesters for Sanitation in Haiti, from 2010 to 2013 -Final Report. 2014. Available online: https:/ / www.susana.org/en/knowledge-hub/resources-and-publications/library/details/2255 (accessed on 24 July 2021).

31. Coelho, S.; Garcilasso, V.; Nunes Ferraz Junior, A.; Santos, M.; Joppert, C. Tecnologias de Produção e Uso de Biogás e Biometano: Part. I Biogás; Part. II Biometano; IEE-USP: São Paulo, Brazil, 2018; ISBN 978-85-86923-53-1.

32. SABESP - Environmental Technology and Sanitation Company. SABESP technical standard NTS 230. Design of stabilization ponds and their complementary sewage treatment Restroom. São Paulo, Brazil, 2009. Available online: https://www3.sabesp. com.br/normastecnicas/nts/nts230.pdf (accessed on 13 September 2021).

33. Smith, J.; Austin, G.; Avery, L.; Balana, B. The potential of small-scale biogas digesters to alleviate poverty and improve long term sustainability of ecosystem services in Sub-Saharan Africa. 2011; DFID NET-RCA06502. Available online: https://assets. publishing.service.gov.uk/media/57a08ad9e5274a31e00007ec/FinalReport_Biogas-Digesters-in-Sub-Saharan-Africa.pdf (accessed on 22 September 2021). 
34. An, B.X. The Role of Low-cost Plastic Tube Biodigesters in Integrated Farming Systems in Vietnam. Livest. Feed Resour. Integr. Farming Syst 1996, 1, 277-294.

35. Schoeber, M.; Rahmann, G.; Freyer, B. Small-scale biogas facilities to enhance nutrient flows in rural Africa-relevance, acceptance, and implementation challenges in Ethiopia. Org. Agric. 2020, 11, 231-244. [CrossRef]

36. Orskov, E.R.; Anchang, K.Y.; Subedi, M.; Smith, J. Overview of holistic application of biogas for small scale farmers in Sub-Saharan Africa. Biomass-Bioenergy 2014, 70, 4-16. [CrossRef]

37. Day, D.; Chen, T.; Anderson, J.; Steinberg, M. Biogas plants for small farms in Kenya. Biomass 1990, 21, 83-99. [CrossRef]

38. Fred, L. Quality and Usage of Biogas Digesters in Uganda; Royal Institute of Technology: Stockholm, Sweden, 2013.

39. Carlsson, H.; Kiste, K. Environmental Sustainability of Floating Biodigesters in Tonle Sap; Lund University: Cambodia, Sweden, 2013.

40. Buntha, P.; Bunsong, S.; Hughes, R.; Kunthel, T.; McGill, G.; Soklim, R. Floating Biodigester for Integrated Waste Management in Agriculture and Energy Production. 2013. Available online: https://www.susana.org/en/knowledge-hub/resources-andpublications/library/details/1768?pgrid=1 (accessed on 24 July 2021).

41. Asian Development Bank. PRC: Efficient Utilization of Agricultural Wastes Project; Asian Development Bank: Mandaluyong, Philippines, 2010; Available online: https:/ / www.adb.org/sites/default/files/project-document/64259/33443-01-prc-pcr.pdf (accessed on 24 July 2021).

42. Hojnacki, A.; Li, L.; Kim, N.; Markgraf, C.; Pierson, D. Biodigester Global Case Studies. D-Lab Waste 2011. Available online: http:/ / www.build-a-biogas-plant.com/PDF/D_Lab_Waste_Biodigester_Case_Studies_Report.pdf (accessed on 24 July 2021).

43. Nijaguna, B.T. Biogas Technology; New Age Intern; (P) limited: Daryaganj, New Delhi, 2002; 300p.

44. Ramatsa, I.; Akinlabi, E.; Madyira, D. Design of the bio-digester for biogas production: A review. Lect. Notes Eng. Comput. Sci. 2014, 2, 628-631.

45. Mutungwazi, A.; Mukumba, P.; Makaka, G. Biogas digester types installed in South Africa: A review. Renew. Sustain. Energy Rev. 2018, 81, 172-180. [CrossRef]

46. Singh, S.P.; Vatsa, D.; Verma, H. Problems with biogas plants in himachal pradesh. Bioresour. Technol. 1997, 59, 69-71. [CrossRef]

47. Luo, T.; Pan, J.; Fu, L.-T.; Mei, Z.; Kong, C.; Huang, H. Reducing biogas emissions from village-scale plant with optimal floating-drum biogas storage tank and operation parameters. Appl. Energy 2017, 208, 312-318. [CrossRef]

48. Rodriguez, L.; Preston, T.R. Biodigester Installation Manual. 2001. Available online: https://www.semanticscholar.org/ paper/Biodigester-installation-manual-Rodr\%C3\%ADguez-Preston/870ee777a1bfc285c160e247039a017ef6a73b27 (accessed on 24 July 2021).

49. Marchaim, U. Biogas Processes for Sustainable Development; Food and Agricultural Organization of the United Nations: Rome, Italy, 1992.

50. Martí-Herrero, J.; Cipriano, J. Design methodology for low cost tubular digesters. Bioresour. Technol. 2012, 108, 21-27. [CrossRef]

51. Zang, J.W.; Da Fonseca Zang, W.A.; Sacho Duarte, S.; De Santana Azevedo, H.L.; Campos, L.C.; Leandro, W.M. Biodigestores para Agricultura Familiar. Booklet. CVT Apinajé, Goiânia, GO, Brazil. PDF, 58p. 2021. Available online: https://wwef-nexus org/wp-content/uploads/2021/03/Cartilha-Biodigestores-Site.pdf (accessed on 13 September 2021).

52. An, B.X.; Rodriguez, J.L.; Sarwatt, S.V.; Preston, T.R.; Dolberg, F. Installation and performance of low-cost polyethylene tube biodigesters on small-scale farms. World Animal Review 88-1997/1. Available online: http:/ /www.fao.org/3/w5256t/w5256t06. htm (accessed on 24 July 2021).

53. Rowse, L.E. Design of Small Scale Anaerobic Digesters for Application in Rural Development Countries; University of South Florida: Hillsborough County, FL, USA, 2011; Available online: https://core.ac.uk/download/pdf/154468889.pdf (accessed on 24 July 2021).

54. Venugopalan, V.; Balasundaram, N.; Hemalatha, S. Comparative Study on Biogas Production from Cow Dung, Food Waste and Organic Wastes. Int. J. Civ. Eng. Technol. 2017, 8, 100-106.

55. Martí-Herrero, J.; Chipana, M.; Cuevas, C.; Paco, G.; Serrano, V.; Zymla, B.; Heising, K.; Sologuren, J.; Gamarra, A. Low cost tubular digesters as appropriate technology for widespread application: Results and lessons learned from Bolivia. Renew. Energy 2014, 71, 156-165. [CrossRef]

56. Singh, G.; Jain, V.K.; Singh, A. Effect of Temperature and other factors on Anaerobic Digestion Process, responsible for Bio Gas Production. Int. J. Theor. Appl. Mech. 2017, 12, 637-657.

57. Kaparaju, P. Enhancing Methane Production in a Farm-Scale Biogas Production System; University of Jyvaskyla: Jyväskylä, Finland, 2003.

58. Zou, S.; Wang, H.; Wang, X.; Zhou, S.; Li, X.; Feng, Y. Application of experimental design techniques in the optimization of the ultrasonic pretreatment time and enhancement of methane production in anaerobic co-digestion. Appl. Energy 2016, 179, 191-202. [CrossRef]

59. Lim, C.; Kim, D.; Song, C.; Kim, J.; Han, J.; Cha, J.-S. Performance and emission characteristics of a vehicle fueled with enriched biogas and natural gases. Appl. Energy 2015, 139, 17-29. [CrossRef]

60. Vijay, V.K.; Kapoor, R.; Trivedi, A.; Vijay, V. Biogas as Clean Fuel for Cooking and Transportation Needs in India. In Advances in Bioprocess Technology; Springer Cham: Basel, Switzerland, 2015; pp. 257-275. [CrossRef]

61. Global Methane Initiative. Successful Applications of Anaerobic Digestion from Across the World. 2013. Available online: https:/ / www.globalmethane.org/documents/gmi\%20benefits\%20report.pdf (accessed on 23 September 2021).

62. Kshirsagar, S.R. Nightsoil Biogas Plants: Health Aspects. Biogas from Hum. Waste (Workshop Report); CORT: New Delhi, India, 1986. 
63. Demont, D.; Sckeyde, A.; Uirich, A. Possible Applications of Bioslurry for the Purposes of Fertilisation. Chang. Villages 1991, 10, 1991.

64. Arthurson, V. Closing the Global Energy and Nutrient Cycles through Application of Biogas Residue to Agricultural LandPotential Benefits and Drawback. Energies 2009, 2, 226-242. [CrossRef]

65. Ghosh, S. Prologue. Biogas from Hum. Waste (Workshop Report); CORT: New Delhi, India, 1986.

66. Khandelwal, K.C.; Mahdi, S.S. Biogas Technology: A Practical Handbook; Tata McGraw: New Delhi, India, $1986 ;$ Volume 1.

67. Orner, K.D.; Camacho-Céspedes, F.; Cunningham, J.A.; Mihelcic, J.R. Assessment of nutrient fluxes and recovery for a small-scale agricultural waste management system. J. Environ. Manag. 2020, 267, 110626. [CrossRef] [PubMed]

68. Oliver, L.; Whitworth, C. Climate Smart Farming for Women in East Africa; Santa Clara University: Santa Clara, CA, USA, 2018.

69. Ediviani, W.; Priadi, C.R.; Moersidik, S.S. Nutrient uptake from liquid digestate using ornamental aquatic macrophytes (Canna indica, Iris pseudacorus, Typha latifolia) in a constructed wetland system. J. Physics: Conf. Ser. 2018, 1022, 012052. [CrossRef] 